\title{
Applying Open Source Practices and Principles in Open Innovation: The Case of the Demola Platform
}

\author{
Terhi Kilamo ${ }^{1}$, Imed Hammouda ${ }^{1}$, Ville Kairamo², Petri Räsänen ${ }^{2}$, \\ and Jukka P. Saarinen ${ }^{3}$ \\ 1 Tampere University of Technology \\ firstname. lastname@tut.fi \\ 2 Uusi Tehdas/New Factory \\ firstname.lastname@hermia.fi \\ ${ }^{3}$ Nokia Research Center \\ jukka.p.saarinen@nokia.com
}

\begin{abstract}
In numerous fields, businesses have to rely on rapid development and release cycles. Variant new ideas and concepts can emerge through open innovation as the participants are not limited to the company scope. This makes open innovation an increasingly appealing option for the industry. One such open innovation platform, Demola, allows university students to work on real life industrial cases of their own interest. We have identified similarities with its way of operation to open source software development and find that it offers a viable motivational, organizational and collaborative solution to open innovation.
\end{abstract}

\section{Introduction}

Constant, lightning-fast innovation is becoming an essential element to companies in software business. Innovation can lie in any commodity it being something novel that can be put to actual use. Many companies rely on innovation on a daily basis to create better products and to improve their internal processes [2]. Traditionally such advantages have been kept within the company.

Opening up the option to innovate to a wider group of partners can enforce and expand the scope of the innovation process, which becomes free of the boundaries of the company and what knowledge is available within. Open innovation helps in identifying the best ideas by combining internal and external ideas into architectures and systems [112]. The open innovation process typically involves proof of concepts, trials, and, perhaps most importantly, the right people to identify what should (or must) be focused on.

Open innovation, however, comes with a number of challenges such as motivation, integration and exploitation of innovation [5]. It needs a governance framework 4] that enables organizational alignment of the different partners, proper handling of intellectual property rights issues, and the emergence of new kinds of business opportunities. These challenges have to be taken into account 
when building any open innovation platform with the goal of driving future development and solutions.

In this paper, we argue that the open source model of development and knowledge creation brings a set of principles of practices that could be adapted to the context of open innovation, in the same way as observed in 10. We focus on open innovation in the context of academia-industry co-operation. In order to support our arguments, we have analyzed an open innovation platform for students called Demola 12 .

We identify characteristics of open source software development in the motivational, organizational, and collaboration aspects of open innovation. The main research question answered is: How Demola's approach shares similarities with other community driven development methods, mainly open source? In Section 2 we give background on the Demola organization and discuss the practices of open source within the open innovation context of Demola in Section 3. Section 4 then concludes the paper with some discussion and final remarks.

\section{Platform for Open Innovation and Learning}

There is a real need for increased opportunities for innovation projects that can lead to new business ideas. Open innovation environments allow businesses to reach beyond the company scope in the search for new concepts and ideas. A governance framework is needed with practices and working principles to bring innovation partners together and to ensure ongoing innovation work.

Demola is one such open innovation platform intended for students. It aims to multidiciplinary and agile development of innovative products and product demos. The project ideas come from the industry and public organisations and thus concepts that have practical business importance are developed. The student work is supported by both the industrial and the academia partners that provide guidance throughout the project. Demola offers a governance framework

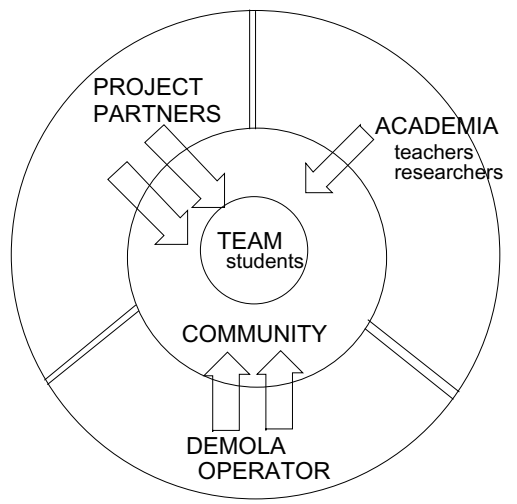

Fig. 1. Demola Partners 
that facilitates team building and supports emerging business ideas. It also incorporates a model for managing immaterial rights that supports startups and respects the authors. On a practical level, Demola provides workspaces that support team work and co-creation. Demola is a modern and actual learning environment to students from different universities.

Figure 1 shows the partners in Demola innovation and the flow of communication and support for the project work. The team is at the heart of development while others direct, aid and facilitate the work. In terms of numbers, there are currently 35 companies involved in Demola as project partners. During 2011 the aim is to reach a yearly level of around 100 projects running. The Demola operator itself employs three people: one manager and two assistants.

\section{Adopting Open Source}

Demola was built on the basis of openness. There are different aspects and challenges that need to be addessed in making the platform open and functional. A set of principles and practices of free/libre open source (FLOSS) can been identified in Demola.

Motivation. A famous quote from Raymond [1] claims that "Every good work of software starts by scratching a developer's personal itch." This is commonly seen as one of the driving forces behind open source software quality and success. The participant's motivation is also one of the main characteristics of Demola team building and work. Similarly Raymond's restatement of the itch: "To solve an interesting problem, start by finding a problem that is interesting to you" is a major driving force in the Demola way of doing.

Internal motivation as driver: The participant's internal motivation is the main driving factor for the Demola team work. Participation is fueled by their own background, motivation and goals that range beyond normal school work.

Participant chooses the project: The way teams are formed in Demola is similar to how open source communities come into being. Students search for project topics that are meaningful and interesting to them and apply for participation in it. The reasons for choosing a project are personal to the applicant with widely varied factors behind the selection. The applicants have no knowledge of the possible other team members in advance and it is not possible to choose the people you form the team with.

Collaboration. Jukka Saarinen, one of the key people behind the the foundation of Demola, has said about the platform: "What is special about Demola is the way of doing things: anyone and everyone can contribute ideas to a demo which is then built together. The let's do it attitude without bureaucracy and formal processes makes the atmosphere fruitful" [8]. This reflects the philosophical standpoint of open source software development. Those with the interest and skill can contribute their work to the community. 
Co-creation: Demola has been built on the notion of bringing the right people together and to enabling collaboration between participants. Demola itself is a developer community where anyone can contribute their work based on their own interest and skill. Similarly the development of the project concepts and demos in Demola is done through collaborative teams. Each team member brings his or her own knowledge and expertise into the team and each team is different.

Community spirit: The student teams, active academia members and the project partners form an innovation ecosystem where all participants benefit from the Demola platform. Demola acts like a community of developers where the teams share ideas and work and where the project partners benefit from the work done in teams for other partners.

Legal Concerns. What is special about open source is its philosophy on intellectual property rights (IPR). The approach chosen for managing the IPR of the project teams in Demola is akin to the idea of licensing in open source. The open innovation approach in Demola respects the IPR of the teams: the students own the rights to the project results. The originator of the project idea can buy wide and parallel usage rights to the results by paying the project team an agreed reward, i.e. the team licences their work to the industrial partner.

\section{Discussion and Conclusions}

We have identified the best practices and principles of FLOSS development within an open innovation platform, Demola. When its way of doing is juxtaposed with the FLOSS principles and practices the common factors are identifiable. FLOSS also enables a better and wider exploitation of the results as the teams hold the rights to their work. Demola not only provides support for the project partners to buy rights to the work but also for the students themselves to start new businesses on top of the results.

Traditional open source principles and practices, however, may fall short in other aspects such as timely delivery, communication, and quality. Such challenges in the daily workflow of the project development need futher management methods on top of FLOSS. How these challenges are met is a focus of future research. Our findings suggest that the open source model offers a viable solution to open innovation in terms of motivational, organizational, and collaborational aspects.

\section{References}

1. Raymond, E.S.: The Cathedral and the Bazaar. O'Reilly Media, Sebastopol (1999)

2. Chesbrough, H.: Open Innovation: Researching a New Paradigm, chapter Open Innovation: A New Paradigm for Understanding Industrial Innovation. Oxford University Press, Oxford (2006)

3. Takeuchi, H., Nonaka, I.: The New New Product Development Game. Harvard Business Review, 137-146 (January-February 1986) 
4. Feller, J., Finnegan, P., Hayes, J., O'Reilly, P.: Institutionalising information asymmetry: governance structures for open innovation. Information Technology \& People 22(4), 297-316 (2009)

5. West, J., Gallagher, S.: Challenges of Open Innovation: The Paradox of Firm Investment in Open-Source Software. R\&D Management 36(3), 319-331 (2006)

6. Beck, K.: Embracing Change With Extreme Programming. Computer 32(10), 70-77 (1999)

7. Beck, K., Beedle, M., van Bennekum, A., Cockburn, A., Cunningham, W., Fowler, M., Grenning, J., Highsmith, J., Hunt, A., Jeffries, R., Kern, J., Marick, B., Martin, R.C., Mellor, S., Schwaber, K., Sutherland, J., Thomas, D.: Manifesto for Agile Software Development (March 2002), http://agilemanifesto.org/ (last visited March 2011)

8. Facilitating Innovation at Demola. Open Threads: Open Innovation Newsletter (April 2009)

9. Abrahamsson, P., Salo, O., Ronkainen, J., Warsta, J.: Agile Software Development Methods Review and Analysis. VTT Publications 478 (2002)

10. Goldman, R., Gabriel, R.P.: Innovation Happens Elsewhere: open source as business strategy. Morgan Kaufmann, San Francisco (2005)

11. Davis, S.: How to Make Open Innovation Work in Your Company. Visions Magazine (December 2006)

12. Demola Innovation Platform, http://www.demola.fi (last visited March 2011) 